\title{
Control of psycho-physiological functions of students with ophthalmologic diseases in the process of physical education
}

\author{
Koryahin V.M., Blavt O.Z., Stadnyk V.V. \\ National University Lviv Polytechnic
}

\begin{abstract}
Purpose:

to analyze dynamic of special health group students' (having ophthalmologic diseases) psychological functions parameters in physical education process.

Material: in experiment 40 special health groups' students with ophthalmologic diseases participated. Psychophysiological tests and tool methodic were used.

Results: $\quad$ numerical values of atenciony abilities at the beginning of the research witnessed about disharmony of information's processing, transformation and storing by students. We observed general tendency to increase of test results, which in most of experimental group students (63.4\%) reached average level. Improvement of motor apparatus lability witnesses about adjustment of trophic and energetic processes as well as their vegetative regulation. Integrative indicator of attention stability was at average level (5 points) at the beginning of the research. During experiment this indicator increased 2.7 times (10-11 points). We determined the presence of correlation between quickness of task's fulfillment and efficiency coefficient $(r=0.655, p<0.05)$.

Conclusions: the received information is a foundation for effective interaction of physical education subjects in the form of personality-oriented technology.

Keywords: students, special health group, psycho-physiological functions, ophthalmologic diseases, control.
\end{abstract}

\section{Introduction}

As on to day the quality of higher education is identified with quality of workable specialists' preparation. Students' health is one of the most relevant questions of the present time $[2,7,10,16]$. Within these problems especially important is effectiveness of special health group (SHG) students' physical education.

It is considered that one of promising directions of progressing in SHG physical education is working out and practical realization of new, highly effective technologies of control and monitoring this process [6, $16,22,35]$. In this context it is noted that high level of student's psycho-physiological sphere functional state ensures effective realization of his/her psycho-motor and intellectual potentials. It also ensures effectiveness of his/ her educational and in the future professional functioning [12, 18, 19, 34].

Analysis of scientific-methodic literature shows that determination of physical education efficiency envisages study of psychological functions' state [4, 19, 22, 34, and 35]. Just these results are correlates of SHG students' psycho-physiological state. It is important in ensuring effective social re-integration and further students' functioning by specialty.

Specialists in this sphere attract attention to the fact that without consideration psycho-physiological potentials it is impossible to ensure physical education efficiency $[5,8,22]$. It is considered that assessment of SHG students' psycho-physiological state and monitoring its dynamic are leading factor for effectiveness of health related educational process control.

However, appealing to theoretical works witness significant scantiness of empiric material concerning psycho-physiological functions' studies in SHG. A number

(C) Koryahin V.M., Blavt O.Z., Stadnyk V.V., 2017

doi:10.15561/18189172.2017.0104 of empiric researches proved purposefulness of control over students' with health problems psycho-physiological; state in SHG physical education [5, 14, 16]. Physical workability dependence on SHG students' psychophysiological functions has been proved and substantiated $[6,16]$.

Nevertheless in scientific literature there is no proper substantiation and analysis of control over psychophysiological functions of SHG students with disorder in some sensor systems (in particular ophthalmologic). In scientific practice there are some proofs on influence of psycho-physiological functions' disorders on visual sensor system [13, 40]. In a number of works influence of physical loads on organism's physiological systems is studied [16, 23, 39]. Influence of physical education on adolescents'(with eyesight problems) social-psychological adaptation has been experimentally proved [21]. Thus, the mentioned problems of control over psycho-physiological functions in students with ophthalmologic diseases has not been solved and experimentally tested. It significantly complicates determination of regular tendencies in this aspect.

Hypothesis: implementation of experimental control technology in SHG physical education envisages study of psycho-physiological functions' state. Its purposefulness is conditioned by significance of finding and studying plausible information at certain stage of students' studying. Close interconnection between visual sensor system's functional state and psycho-physiological mechanisms, ensuring students' professional workability can be used as an indicator of students' psycho-physiological state and criterion of workability.

The purpose of the research: is to analyze dynamic of special health group students' (having ophthalmologic diseases) psychological functions parameters in physical education process. 


\section{Material and methods}

Participants: in experiment 40 special health groups' students with ophthalmologic diseases from NU "Lvivska politechnika" participated during three years' physical education course (boys and girl equal number). By results of medical examination the students of the tested sample were related to SHG. All students gave written consent for participation in experiment. Four groups (two - boys' and two - girls') control groups (CG) and experimental groups (EG) were formed as per principle of cluster analysis for sample's distribution into uniform groups. The latter were combined by mutual characteristic (nosological) providing satisfaction of requirements concerning sufficiency of sample's volume at confidence level $\mathrm{p}<0.05$.

The procedure: we fulfilled monitoring of psychophysiological functions' parameters at the beginning and at the end of physical education course as per operationalprocedure criterion (with control measurements and generalization of results). Standard, short, restricted in time psycho-physiological tests were used. Strength and mobility of nervous processes was studied by psychomotor indicators with the help of short informative "Tapping test" [18]. Assessment of mental endurance, workability, cognitive functions and atenciony abilities (ability to distribute attention between several activities simultaneously) was fulfilled with a number of the most known methods. Methodic "Technique Munsterberg» is directed at determination of attention parameters [37]. Bourdon's correcting test (Benjamin B. Bourdon) letter variant) [32] serves for assessment of attention, psychomotor functioning temp, workability and stability in conditions of monotonous functioning. Fulfillment of this test requires constant concentration of attention in conditions of long lasted visual analyzer's overloading. Test of Pieronne- Rouser is: indicators identify features of attention (concentration, stability, selectivity and quickness of re-switching; accuracy and reliability of information processing and workability level) [18].

The selected for empiric study test methods relate to diagnostic methods, which are permitted for application in educational establishments. They are multi-factorial, standardized; they do not set too much requirements and have high level of authenticity. These methods are suitable for application in our sample and do not require special conditions.

For testing simple motor-visual reaction and visual analyzer's lability we used an instrument for neurodynamic testing [41].

Statistical analysis: the received data were characterized with the help of descriptive statistic methods. The main one-dimensional values: mean arithmetic $(X)$, standard deviation $(S)$, median $(M e)$, asymmetry coefficient $\left(A_{s}\right)$, variation coefficient $(V)$. Indicators' increment during experiment was determined by formula [9, 11, and 30] with application the data, taken at the beginning and at the end of the research. Statistical significance was determined with the help of inductive statistic methods (Student's t-criterion).
Statistical processing of the obtained material was carried out with the help of program «Statistica 8.0.», adapted to medical-biological researches.

\section{Results}

Results of monitoring at the beginning of EG and CG students' psycho-physiological functions' research did not confidently differ that was statistically proved (see table 1 ). So, the formed sample completely meets requirements of representativeness.

Neuro-physiological basis of individual difference between students of the same nosology are individualtypological properties of supreme nervous functioning [20]. Characteristic features of the latter are formed under influence of factors of available ophthalmologic problems. So, numerical values of atenciony abilities at the beginning of the research witnessed about disharmony in information's processing, transformation and storing by students of the tested groups.

For determination of experimental technology effect we formed the measure of the tested parameters' development, considering their dynamic (see table 2).

Nervous processes' strength is an indicator of nervous system's workability $[18,23]$. Study of its dynamic gives main information about qualitative analysis of mental workability as indicator of organism's functional state. It was realized with the help of psycho-motor features express-diagnostic - “Tapping test”.

The received coefficient of nervous system's mobility is an indicator of dynamic workability [12]. At the beginning of experiment $5.2 \%$ of students had the first degree; all the rest - second. No person with high degree was found in the sample. Reduction of quantity of points from square to square was observed in most of students. It witnessed about insufficient functional stability of nervous-muscular apparatus.

After finishing experiment in EG there were 89.6\% persons, whose dynamic of coefficient of nervous system's mobility was registered as positive at average degree. We think that the received data are the results of strengthening of nervous system's temp potentials. They are conditioned by complex of central and periphery reconstructions in its state. As a result, under influence of morphological changes in students' organisms increase of nervous processes mobility happens. It basis is perfection of coordination. Visual analysis of rhythmic movements showed increase of sensor-motor workability in EG at the end of experiment.

Maximal frequency in "Tapping test" is one of indicators of psycho-motor activity's quickness; one of integral signs of its lability [14]. It determines development level of such synthesized parameter as quickness of central processing of information before taking decision (motor apparatus lability) [16, 20]. In students of the tested groups its indicators were below average (by 10-points scale) at the beginning of experiment). It witnessed exhaustion of plastic and strengthening of inert processes in central nervous system. Improvement of motor apparatus lability 
Table 1. Indicators of psycho-physiological functions parameters of students with ophthalmologic diseases at the beginning of experiment

\begin{tabular}{|c|c|c|c|c|c|c|c|c|c|c|c|c|}
\hline \multirow{2}{*}{$\begin{array}{l}\text { Description of } \\
\text { parameters }\end{array}$} & & \multicolumn{5}{|c|}{$E G(n=20)$} & \multicolumn{6}{|c|}{ CG $(n=20)$} \\
\hline & & $x$ & $S$ & As & $M e$ & $V$ & $x$ & $S$ & As & Me & $V$ & p \\
\hline \multirow{2}{*}{ DE conv.un. } & $X$ & 6.06 & 0.81 & 0.28 & 6.01 & 36.4 & 6,01 & 0.97 & 0.39 & 5.89 & 33.9 & $>0.05$ \\
\hline & $\mathrm{G}$ & 6.21 & 0.93 & 0.37 & 6.19 & 37.5 & 6,14 & 0.89 & 0.02 & 6.00 & 30.1 & $>0.05$ \\
\hline \multirow{2}{*}{ LMA conv.un. } & B & 2.98 & 0.54 & 0.05 & 2.92 & 37.4 & 2,90 & 0.61 & 0.38 & 2.87 & 28.4 & $>0.05$ \\
\hline & G & 2.55 & 0.61 & 0.38 & 2.53 & 36.2 & 2,63 & 0.77 & 0.04 & 2.55 & 23.9 & $>0.05$ \\
\hline \multirow{2}{*}{ CNSM,\% } & $B$ & 0.68 & 0.12 & 0.29 & 0.65 & 34.7 & 0,70 & 0.09 & 0.15 & 0.69 & 29.8 & $>0.05$ \\
\hline & G & 0.66 & 0.08 & 0.19 & 0.64 & 34.5 & 0,65 & 0.11 & 0.38 & 0.63 & 37.2 & $>0.05$ \\
\hline \multirow{2}{*}{$\begin{array}{l}\text { Assessment } \\
\text { "AcAc", points }\end{array}$} & B & 8.55 & 0.86 & 0.12 & 8.39 & 39.0 & 8,65 & 1.11 & 0.26 & 8.55 & 31.2 & $>0.05$ \\
\hline & G & 8.01 & 1.05 & 0.40 & 7.98 & 40.4 & 8,99 & 0.95 & 0.43 & 8.77 & 33.4 & $>0.05$ \\
\hline \multirow{2}{*}{ At, points } & B & 6.91 & 0.94 & 0.12 & 6.67 & 28.0 & 7,01 & 1.12 & 0.21 & 6.79 & 42.3 & $>0.05$ \\
\hline & G & 7.43 & 0.84 & 0.36 & 7.21 & 34.2 & 7,41 & 0.82 & 0.64 & 7.10 & 47.5 & $>0.05$ \\
\hline \multirow{2}{*}{ At,\% } & B & 70.23 & 2.11 & 0.23 & 69.80 & 22.2 & 71,54 & 3.15 & 0.04 & 69.3 & 47.8 & $>0.05$ \\
\hline & G & 74.18 & 3.09 & 0.01 & 73.01 & 24.5 & 72,76 & 4.11 & 0.42 & 70.02 & 45.7 & $>0.05$ \\
\hline \multirow{2}{*}{$E$} & B & 1290 & 82.8 & 0.36 & 1286 & 24.6 & 1291 & 108.2 & 0.18 & 1287 & 36.8 & $>0.05$ \\
\hline & G & 1353 & 105.2 & 0.19 & 1350 & 27.6 & 1341 & 103.6 & 0.47 & 1339 & 37.5 & $>0.05$ \\
\hline \multirow{2}{*}{$\mathrm{C}, \%$} & B & 38.18 & 5.9 & 0.41 & 37.69 & 27.9 & 37,66 & 5.6 & 0.18 & 36.11 & 37.4 & $>0.05$ \\
\hline & G & 42.64 & 5.3 & 0.25 & 41.33 & 45.7 & 41,03 & 6.2 & 0.08 & 40.33 & 36.2 & $>0.05$ \\
\hline \multirow{2}{*}{$\operatorname{Pr}, \%$} & B & 45.14 & 3.23 & 0.28 & 43.22 & 33.6 & 45,75 & 4.3 & 0.34 & 43.12 & 34.7 & $>0.05$ \\
\hline & G & 48.78 & 3.01 & 0.42 & 46.28 & 37.8 & 50,30 & 4.1 & 0.00 & 48.90 & 34.5 & $>0.05$ \\
\hline AtS, conv. & B & 55.90 & 4.04 & 0.25 & 54.12 & 39.0 & 53,42 & 5.8 & 0.18 & 50.32 & 39.0 & $>0.05$ \\
\hline un. & G & 60.34 & 5.15 & 0.15 & 60.01 & 27.9 & 59,15 & 4.1 & 0.06 & 58.67 & 40.4 & $>0.05$ \\
\hline \multirow[b]{2}{*}{$\mathrm{t}, c$} & B & 249.3 & 30.3 & 0.28 & 245.1 & 26.4 & 248,2 & 29.7 & 0.39 & 246.9 & 38.9 & $>0.05$ \\
\hline & G & 230.5 & 28.8 & 0.37 & 227.3 & 24.6 & 227,1 & 28.5 & 0.39 & 225.9 & 31.7 & $>0.05$ \\
\hline \multirow{2}{*}{$\begin{array}{l}\text { CMW, } \\
\text { conv.un. }\end{array}$} & B & 0.65 & 0.11 & 0.05 & 0.64 & 35.4 & 0,67 & 0.09 & 0.38 & 0.63 & 35.1 & $>0.05$ \\
\hline & G & 0.63 & 0.07 & 0.38 & 0.63 & 29.8 & 0,65 & 0.05 & 0.24 & 0.63 & 29.7 & $>0.05$ \\
\hline \multirow{2}{*}{$\begin{array}{l}\text { LP SVMR, } \\
\text { m.sec. }\end{array}$} & B & 339.3 & 10.4 & 0.29 & 334.3 & 37.2 & 327,6 & 11.5 & 0.15 & 325.7 & 43.4 & $>0.05$ \\
\hline & G & 321.5 & 9.3 & 0.19 & 319.0 & 31.2 & 317,6 & 11.8 & 0.58 & 315.3 & 39.1 & $>0.05$ \\
\hline \multirow[b]{2}{*}{ LVA, $H z$} & B & 29.18 & 1.52 & 0.12 & 28.5 & 33.4 & 28,73 & 1.18 & 0.26 & 27.42 & 33.5 & $>0.05$ \\
\hline & $\mathrm{G}$ & 30.28 & 1.77 & 0.40 & 29.44 & 42.3 & 30,08 & 1.55 & 0.13 & 28.98 & 26.7 & $>0.05$ \\
\hline
\end{tabular}

Legend: DE- dynamic endurance; LMA - lability of motor apparatus; CNSM -coefficient of nervous system's mobility; At - re-switching of attention; Ac - accuracy of attention; E - coefficient of mental workability; C - concentration of attention; AtS - attention stability; $\mathrm{Pr}$ - effectiveness of work; $\mathrm{t}$ - selectiveness of sample; CMW - coefficient of mental workability; LP SVMR- latent period of simple visual-motor reaction; LVA - lability of visual analyzer; $p$ - confidence of difference; B - boys; G - girls.

in EG at the end of experiment witnessed improvement of trophic and energetic processes and their vegetative regulation.

Analysis of motor system's stability showed that boys' results were confidently $(p<0.001)$ better than girls' results. Tapping test's results are substantiated in the aspect of available ophthalmologic disorders in students of the tested groups. At the same time we observed instability of attention and insufficiency of activity.

In general, positive changes in EG students by all parameters of "Tapping test" shows improvement of nervous-muscular apparatus and increase of balance to the side of excitement. Accordingly, correlation of hits and misses in test's results permits to speak about improvement of space coordination functional state in EG after experiment.

By integrative assessment of all tested parameters after experiment we observed general tendency to improvement of test results. Results of the most of EG students (63.4\%) were at average level.

In systemic psycho-physiology attention is not regarded as independent psychic process. It is positioned as reflection of intra-systems' relations of current functioning, which ensure effectiveness of this functioning 
Table 2. Indicators of psycho-physiological functions parameters of students with ophthalmologic diseases after experiment

\begin{tabular}{|c|c|c|c|c|c|c|c|c|c|c|c|c|c|}
\hline \multirow{3}{*}{\multicolumn{2}{|c|}{$\begin{array}{l}\text { Description } \\
\text { of param- } \\
\text { eters }\end{array}$}} & \multicolumn{6}{|c|}{ EG $(n=20)$} & \multicolumn{6}{|c|}{$C G(n=20)$} \\
\hline & & \multicolumn{2}{|c|}{ Before } & \multicolumn{2}{|l|}{ After } & \multirow{2}{*}{$\begin{array}{l}+ \\
(\%)\end{array}$} & \multirow{2}{*}{$p$} & \multicolumn{2}{|c|}{ Before } & \multicolumn{2}{|l|}{ After } & \multirow{2}{*}{$\begin{array}{l}+ \\
(\%)\end{array}$} & \multirow{2}{*}{$\mathbf{p}$} \\
\hline & & $x$ & $S$ & $x$ & $S$ & & & $x$ & $S$ & $x$ & $S$ & & \\
\hline DE conv. & B & 6,06 & 0,81 & 4,85 & 0,95 & 19,9 & $<0,05$ & 6,01 & 0,97 & 5,92 & 0,94 & 1,4 & $>0,05$ \\
\hline un. & G & 6,21 & 0,93 & 5,05 & 0,91 & 18,6 & $<0,05$ & 6,14 & 0,89 & 6,02 & 0,98 & 1,9 & $>0,05$ \\
\hline LMA & B & 2,98 & 0,54 & 3,91 & 0,63 & 30,2 & $<0,001$ & 2,90 & 0,61 & 2,97 & 0,72 & 2,4 & $>0,05$ \\
\hline conv.un. & G & 2,55 & 0,61 & 3,34 & 0,58 & 31,3 & $<0,001$ & 2,63 & 0,77 & 2,67 & 0,64 & 1,51 & $>0,05$ \\
\hline \multirow{2}{*}{ CNSM,\% } & B & 0,68 & 0,12 & 0,88 & 0,07 & 29,4 & $<0,01$ & 0,70 & 0,09 & 0,72 & 0,07 & 2,8 & $<0,05$ \\
\hline & G & 0,66 & 0,08 & 0,81 & 0,09 & 22,7 & $<0,01$ & 0,65 & 0,11 & 0,65 & 0,10 & 0 & $>0,05$ \\
\hline $\begin{array}{l}\text { Assess- } \\
\text { ment }\end{array}$ & B & 8,55 & 0,86 & 10,85 & 0,34 & 26,5 & $<0,01$ & 8,65 & 1,11 & 8,81 & 1,03 & 2,1 & $>0,05$ \\
\hline $\begin{array}{l}\text { "AcAc", } \\
\text { points }\end{array}$ & G & 8,01 & 1,05 & 9,61 & 0,68 & 20,8 & $<0,05$ & 8,99 & 0,95 & 8,08 & 0,84 & 1,2 & $>0,05$ \\
\hline \multirow{2}{*}{ At, points } & B & 6,91 & 0,94 & 9,12 & 1,15 & 28,5 & $<0,01$ & 7,01 & 1,12 & 7,16 & 0,79 & 1,2 & $>0,05$ \\
\hline & G & 7,43 & 0,84 & 10,05 & 1,01 & 31,6 & $<0,001$ & 7,41 & 0,82 & 7,45 & 0,83 & 2,4 & $>0,05$ \\
\hline \multirow{2}{*}{ At, $\%$} & B & 70,23 & 2,11 & 86,14 & 2,88 & 22,8 & $<0,05$ & 71,54 & 3,15 & 75,62 & 2,28 & 5,6 & $<0,05$ \\
\hline & G & 74,18 & 3,09 & 90,51 & 2,16 & 21,6 & $<0,05$ & 72,76 & 4,11 & 77,33 & 3,01 & 6,8 & $<0,05$ \\
\hline \multirow{2}{*}{$E$} & B & 1290 & 82,8 & 1598 & 91,8 & 23,4 & $<0,05$ & 1291 & 108,2 & 1335 & 108,1 & 3,08 & $<0,05$ \\
\hline & G & 1353 & 105,2 & 1702 & 102,6 & 25,8 & $<0,01$ & 1341 & 103,6 & 1355 & 90,8 & 1,04 & $>0,05$ \\
\hline \multirow{2}{*}{$\mathrm{C}, \%$} & B & 38,18 & 5,9 & 50,33 & 4,7 & 31,5 & $<0,001$ & 37,66 & 5,6 & 38,91 & 6,2 & 2,6 & $>0,05$ \\
\hline & G & 42,64 & 5,3 & 56,41 & 6,0 & 32,4 & $<0,001$ & 41,03 & 6,2 & 43,15 & 5,3 & 2,8 & $<0,05$ \\
\hline \multirow{2}{*}{$\operatorname{Pr}, \%$} & B & 45,14 & 3,23 & 54,72 & 4,71 & 20,8 & $<0,05$ & 45,75 & 4,3 & 47,3 & 3,8 & 4,4 & $<0,05$ \\
\hline & G & 48,78 & 3,01 & 60,11 & 5,74 & 25,1 & $<0,01$ & 50,30 & 4,1 & 52,2 & 3,5 & 4,1 & $<0,05$ \\
\hline Ats, & B & 55,90 & 4,04 & 70,47 & 5,9 & 26,7 & $<0,01$ & 53,42 & 5,8 & 55,4 & 5,6 & 3,7 & $<0,05$ \\
\hline conv.un. & G & 60,34 & 5,15 & 78,18 & 5,3 & 29,5 & $<0,001$ & 59,15 & 4,1 & 61,1 & 4,2 & 3,3 & $<0,05$ \\
\hline \multirow{2}{*}{$\mathrm{t}, \mathrm{c}$} & B & 249,3 & 30,3 & 167,4 & 32,9 & 32,1 & $<0,001$ & 248,2 & 29,7 & 235,1 & 19,2 & 5,2 & $<0,05$ \\
\hline & G & 230,5 & 28,8 & 156,1 & 28,3 & 33,0 & $<0,001$ & 227,1 & 28,5 & 213,3 & 21,8 & 5,9 & $<0,05$ \\
\hline \multirow{2}{*}{$\begin{array}{l}\text { CMW, } \\
\text { conv.un. }\end{array}$} & B & 0,65 & 0,11 & 0,83 & 0,07 & 33,8 & $<0,001$ & 0,67 & 0,09 & 0,71 & 0,06 & 6,5 & $<0,05$ \\
\hline & G & 0,63 & 0,07 & 0,80 & 0,09 & 26,9 & $<0,001$ & 0,65 & 0,05 & 0,68 & 0,08 & 4,6 & $<0,05$ \\
\hline \multirow{2}{*}{$\begin{array}{l}\text { LP SVMR, } \\
\text { m.sec. }\end{array}$} & B & 339,3 & 10,4 & 290,4 & 7,3 & 14,7 & $<0,05$ & 327,6 & 11,5 & 326,2 & 9,9 & 0 & $>0,05$ \\
\hline & G & 321,5 & 9,3 & 275,9 & 11,4 & 14,1 & $<0,05$ & 317,6 & 11,8 & 318,6 & 10,3 & 0 & $>0,05$ \\
\hline \multirow{2}{*}{ LVA, $\mathrm{Hz}$} & B & 29,18 & 1,52 & 39,93 & 1,23 & 30,2 & $<0,001$ & 28,73 & 1,18 & 30,15 & 1,82 & 0,5 & $>0,05$ \\
\hline & G & 30,28 & 1,77 & 40,56 & 1,67 & 30,7 & $<0,001$ & 30,08 & 1,55 & 31,52 & 1,07 & 0,5 & $>0,05$ \\
\hline
\end{tabular}

and mental workability $[12,18]$. Indicator of task's fulfillment accuracy depends on functional state of nervous system, degree of stability and attention fatigue. Finally it determines the quality of fulfilled work [12]. Before the end of experiment qualitative values of this parameter in EG reach positive dynamic up to $30 \%(p<0.05)$.

Indicator of work efficiency characterizes quickness of perception and thinking. It depends on nervous processes mobility [13]. Reaching of nervous system excitation's utmost under influence of trainings created favorable conditions for increase of attention's efficiency in EG. Integrative indicator of attention stability at the beginning of the research was at average level (5 points). During experiment this indicator increased 2.7 times (10-11points). At the same time we found the presence of correlation between quickness of task's fulfillment and coefficient of efficiency $(r=0.655, p<0.05)$.

Implementation of experimental technology in EG educational process conditioned substantial improvement of atenciony abilities' indicators. The latter condition success in any professional functioning. They take leading place in its psycho-physiological structure [12]. Integrative indicator of atenciony abilities increased in EG in average up to $33 \%(\mathrm{p}<0.05)$. Numerical values of concentration, stability, re-switching and selectivity of attention reached average and good levels. All these are the main factor of work's and mental workability's high effectiveness [16].

Physiological base of attention is brain activation, connected with reticular formation's functioning [13]. In a number of cases indicator of the tested number of abilities is lower than possible because of health problems, asthenic state or fatigue. Thus, we can observe influence of ophthalmologic diseases on atenciony abilities. At the beginning of the research their level was low. Improvement of qualitative values up to average level is, to some extent, an evidence of improvement of morphological state in EG. 
Attention concentration was low and rigid nearly in all students of the tested sample at the beginning of experiment. It is explained by increased load on visual analyzer and possible Gnostic disorders. The reason of attention concentration's weakening is also bad eyesight. It is considered that concentration of attention is trained rather easily [12, 20]. After experiment it increased to good level $-87.8 \%$ in EG. Such data are the results of improvement of general brain activation under influence of trainings.

Indicators of attention re-switching [20] were low in the tested groups at the beginning of experiment. After its' finishing their confident increment was observed as well as reaching of average level in EG. It resulted from optimal activation of reticular system that ensured such dynamic. Level of confidence of the changes in the tested parameters in EG was rather high.

In systemic psycho-physiology mental workability is conditioned by level of cognitive functions and atenciony abilities [16, 18]. Together they reflect such intrasystems relations of psycho-physiological functions, which ensure effectiveness of functioning. Development of mental workability goes as per general ontogeny laws. But the structure and complexity of its formation require correction psycho-physiological mechanisms of its progressing through physical culture. Besides, mental workability indicators have complex indirect dependence on indicators of physical workability [23]. As a result of our research in EG coefficient of mental workability reached to single values. Between average values of mental workability coefficients of EG boys and girls we found no confident differences during experiment $(\mathrm{p}>0.05)$.

In mental functioning visual analyzer endures the main load [16]. In this aspect we considered purposeful to study the following: the functions, connected with visual perception of information and functional state of central nervous system. Determination of sensor-motor reaction's indicators was conditioned by demand in consideration functional mobility of nervous processes. The latter ensure effectiveness of professional activity.

By results of simple visual-motor reaction we judged about effectiveness of visual information's processing. Before experiment latent period was low in all students. We assumed that it as explained by influence of ophthalmologic diseases on physiological responses of students' organisms to the offered stimuli of reactions. The received results are completely substantiated from the point of physiology. Quickness of sensor-motor responding to large extent determines functional state of central nervous system [1]. It manifested as regress of quickness and accuracy of responding to external signal. It elongated the time of reaction. We do not exclude also influence of active formation of brain informational processes' bases on reduction of students' responding time. It is characteristic for such age period [16].

Indicator of visual analyzer's lability is integrative assessment of central nervous system's lability and changes of its functional state. It ensures the function of information scanning in real time [35]. Before the research indicator of light blinking discreteness in EG was at level $1-2$ points $(\leq 30 \mathrm{~Hz})$. After experiment, in control group the most typical changes in emotional lability were gradual dynamic increase of its criterion indicators. We observed confident $(p<0.001)$ improvement of nervous processes' mobility indicators. Their positive dynamic was within up to $30 \%$. In points it was 7 points.

In study of psycho-physiological functions' neurodynamic block we found a number of differences between measures of reactions by signs of gender dimorphism. All tested indicators of girls confidently were higher than boys' at significance level ( $>00.001)$. Nosological distribution of reaction time has positive asymmetry.

Especially different are qualitative results of neurodynamic block parameters' testing in the tested groups. It manifested as quickness and accuracy regress in responding to external signal (elongation of reaction time). Evidently, it is conditioned by their physiological characteristics and disorders of visual sensor system's functional components. Accordingly, substantial positive dynamic of the tested parameters is conditioned by improvement of this system's state; changes in motor component's organization; reduction of deviations in visual analyzer.

The study of psycho-physiological functions permitted to determine that change of the tested parameters in CG is characterized by absence of positive tendency both in boys and girls. Some indicators manifested positive tendency in the process of training. However, at finalizing stage they, in general, did not confidently differ $(p>0.05)$ from the beginning stage. The mentioned above shows weakening of energetic and regulatory processes in central nervous system. It objectively manifests in regress of psycho-physiological functions' parameters. Absence of positive dynamic in indicators of visual analyzer's lability witnesses about asthenia. Mental workability coefficient in CG students insignificantly but confidently reduces during the whole period of training $(\mathrm{p}<0.001)$.

\section{Discussion}

We completely support scientific approaches of scientists, who deal with optimization of control in physical education [2, 6, 16, 19, 24]. In this aspect, the state of psycho-physiological functions is one of important criteria of mental workability. The latter is limited by organism's reserves, pathological changes in visual sensor system $[12,16,35]$. Numerical scientific data $[8$, $13,16,34]$ witness that studies of psycho-physiological functions gives additional information about functional state of students' organisms.

We expanded and supplemented information [2, 6, $7,35]$ about studies of important parameters of SHG students' psycho-physiological functions' parameters. There are many evidences that they are determining factors of students' psych-physiological readiness for future professional functioning. In contrast to previous researches of SHG we fulfilled experiment in compliance with addressed nosology. 
In the base of test selection were results of well known scientists' works. It was determined by the fact that formation of professional skillfulness is conditioned by individual's cognitive, regulatory and sensor-motor sphere. It is limited by state of sensor integration in processes of perception and memory. Actually it conditions success in any professional activity [12-20, 33, 34]. Their state is regarded as criterion of physical education effectiveness in removal of evident health problems [6, 21, 35].

Atpresent, searches of mechanism of mentalworkability control of SHG students with ophthalmological diseases with application of definite motor functioning forms are still fragmentary, insufficient and not substantiated. By scientific data $[12,18,20,23]$ such situation is conditioned by central nervous system's state as well as the senses. We used scientific data about tests' application for diagnostic. It is limited by organism's reserves and available pathological deviations in visual system $[5,16$, 19]. Positive dynamic of mental workability in EG is a proof of it.

We proved that psycho-physiological functions' state depends on sex $[12,13,18]$. In indicators of the tested parameters the most significant differences were determined by sex dimorphism. In boys of EG improvement of mental workability and endurance was confidently $(p<0.05)$ better than in girls. The EG girls' better changes (confident at $\mathrm{p}<0.05$ ) were in atenciony abilities. Such tendency is quite logical, considering sex aspects of individual ontogeny. The latter are characterized by certain intensity of physiological systems functions' development. They also determine quantitative changes of certain parameters: gender properties of attention and so on. As specialists $[12,16,18,20]$ think it does not concern mental workability. It is proved by results of experiment. We found no confident differences between mental workability coefficient of EG boys and girls during experiment $(\mathrm{p}>0.05)$.

According to scientific data $[1,16,20,23]$ ophthalmological diseases condition organism's physiological reactivity. The received by us results prove that such pathologies determine low level of students' psycho-physiological functions. As a result the time of simple visual-motor reaction becomes longer. It proves the presence of permanent psycho-physiological functions interconnection with organism's morphological functional state $[12,16,18$, and 23]. Indicator of task's fulfillment accuracy depends on nervous system's functional state, degree of attention stability and fatigue. In total, it determines the quality of fulfilled work. This important principle of pathogenesis is conditioned by leading role of central nervous system and influence of visual sensor system's available diseases. They disorder its normal functioning $[1,23]$. Assessment results of main nervous processes' mobility in visual analyzer prove conclusions of scientists that in students with eyesight problems the process of information processing differs by regress of quickness and dynamic of information receiving $[1,23,35]$.

The received results supplement our own researches [4-6, 14] on realization of experimental control technology in SHG. The predicted effect of the conducted experiment was efficiency of implemented technology. It was proved by positive dynamic of the tested parameters.

We proved numerical scientific data $[2,7,19,22]$ about low effectiveness of acting physical education system in SHG of higher educational establishments.

\section{Conclusions}

The purposefulness of psycho-physiological functions diagnostic in the conducted experiment is conditioned by the fact that such functions ensure success in any professional functioning. Consideration of individual psycho motor abilities permits to find the level of professional fitness.

Generalized statistic analysis of testing results of SHG students' psycho-physiological functions permits to conclude that it is necessary to implement the worked out technology in physical education. We witnessed increase of mental workability and positive dynamic of cognitive functions against the background of visual sensor system's improvement. We stated their diachronic coincidence in CG (at level $\mathrm{p}>0.05$ ) before and after experiment. With it there is diachronic difference (at level $\mathrm{p}<0.05$ ) in EG before and after experiment. Before and after experiment between EG and CG there is synchronic difference. With it confidence of differences of the tested students was at level $\mathrm{p}<0.05$.

Systemizing and generalization of all tested parameters' final results witness in favor of implemented technology. Experience of EG trainings permits to state positive effect of targeted correction impacts in the course of physical education. It is witnessed by absolute values of psycho-physiological functions' parameters at finalizing stage. The received information is the base for effective interaction of physical education subjects in the form of personality-oriented anthropic technology.

\section{Conflict of interests}

The authors declare that there is no conflict of interests. 


\section{References}

1. Apanasenko GL, Mikhajlovich SO. Fiziologichni osnovi fizichnoi kul turi i sportu [Physiological principles of physical culture and sports], Uzhgorod; 2004. (in Ukrainian)

2. Bielogurova LV, Ribkovs'kij AG, Chamata OO. Fizichne vikhovannia studentiv u special'nikh medichnikh grupakh [Physical education of students in special health groups], Donets'k: DNU; 2010. (in Ukrainian)

3. Blavt OZ. Informative indicator of physical health and physical fitness of university students. Pedagogics, psychology, medical-biological problems of physical training and sports, 2012;11:14-19.

4. Blavt OZ. Konceptual'ni polozhennia organizacii i formuvannia zmistu testovogo kontroliu studentiv $\mathrm{u}$ fizichnomu vikhovanni special'nikh medichnikh grup [Conceptual principles of organization and formation of students test control content in physical education in special health groups]. Molodizhnij naukovij visnik, 2015;19:50-55. (in Ukrainian)

5. Blavt OZ. Psikhofiziologichna diagnostika u konteksti formuvannia sistemi kontroliu u fizichnomu vikhovanni studentiv special'nikh medichnikh grup [Psychophysiological diagnostic in context of control system's formation in physical education of special health groups' students]. Naukovo-pedagogichni problemi fizichnoi kul 'turi, 2015;56(15):66-70. (in Ukrainian)

6. Blavt O. Sistema kontroliu u fizichnomu vikhovanni studentiv special'nikh medichnikh grup [System of control in physical education of special health groups' students], Lviv: Lviv Polytechnic Publ.; 2016. (in Ukrainian)

7. Bulkina N.P. K voprosu o fizicheskom vospitanii studentov special'noj medicinskoj gruppy [On physical education of special health groups' students]. Pedagogics, psychology, medical-biological problems of physical training and sports, 2008;6:171-173.

8. Vlasova TS, Sungatullin RI, Zakirova NM. Osobennosti fizicheskogo vospitaniia studentov, imeiushchikh otkloneniia v zdorov'e [Peculiarities of physical education of students, having health problems]. Molodoj uchenyj, 2015;5:441-443. (in Russian)

9. Godik MA. Sportivnaia metrologiia [Sports metrology], Moscow: Physical Culture and Sport; 1988. (in Russian)

10.Zhmykhova AIu. Korrekcionnaia napravlennost' fizicheskoj podgotovki studentov special'noj medicinskoj gruppy na osnove ikh morfofunkcional'nykh osobennostej. Kand. Diss. [Correction orientation of physical training of special health groups' students, based on their morphological functional characteristics. Cand. Diss.], Moscow; 2010. (in Russian)

11.Zaciorskij VM. Osnovy sportivnoj metrologii [Principles of sport metrology], Moscow: Physical Culture and Sport; 2006. (in Russian)

12.Korobejnikov GV. Psikhofiziologiia deiatel'nosti cheloveka [Psycho-physiology of human activity], Saarbrucken: LAP Lambert Academic Publishing; 2011. (in Russian)

13.Korobejnikov GV. Psikhofiziologicheskie mekhanizmy umstvennoj deiatel'nosti cheloveka [Psycho-physiological mechanisms of human mental functioning], Kiev: Ukrainian fito sociological center; 2002. (in Ukrainian)

14.Koriagin VM, Blavt OZ. Testovyj kontrol'v fizicheskom vospitanii [Test control in physical education], Germany: LAP LAMBERT Academic Publishing; 2013. (in Russian)

15.Koriagin VM, Blavt OZ. Fizichne vikhovannia studentiv $u$ special'nikh medichnikh grupakh [Physical education of special health groups' students], Lviv: Lviv Polytechnic Publ.; 2013. (in Ukrainian)
16.Magl'ovanij AV, Safronova GB, Galajtatij GD, Bielova LA. Pracezdatnist' studentiv: ocinka, korekciia, upravlinnia [Students' workability: assessment, correction, control], Lviv; 1997. (in Ukrainian)

17.Malikov MV, Svat'iev AV, Bogdanovs'ka NV. Funkcional'na diagnostika u fizichnomu vikhovanni $i$ sporti [Functional diagnostic in physical education and sports], Zaporizhzhya: ZSU; 2006. (in Ukrainian)

18.Aleksandrov IuI. Osnovy psikhofiziologii [Principles of psycho-physiology], Moscow: Infra; 1998. (in Russian)

19.Popichev MI. Complex diagnostics and estimation of health of students level. Physical Education of Students, 2011;3:7175 .

20.Aleksandrov IuI. Psikhofiziologiia [Psychophysiology], Sankt Petersburg: Peter; 2001. (in Russian)

21.Savchenko DV, Mironova VI, Babich EG, Morozov VA. Vliianie komandno-igrovykh vidov sporta na social'nopsikhologicheskuiu adaptaciiu podrostkov s narusheniem zreniia v kollektive sverstnikov [Influence of team-game kinds of sports on social-psychological adaptation of adolescents with visual disorders in collective of peers]. Teoriia i praktika fizicheskoj kul'tury, 2016;3:38-40. (in Russian)

22.Stoliarov VI. Teoriia $i$ metodologiia sovremennogo fizicheskogo vospitaniia [Theory and methodology of modern physical education], Kiev: Olympic Literature; 2015. (in Russian)

23.Tolmachev RA. Osobennosti reakcii nekotorykh fiziologicheskikh sistem organizma sportsmenov-invalidov po zreniiu na fizicheskie nagruzki [Peculiarities of reactions of some organism's physiological systems of disabled sportsmen on physical loads]. Mediko-social'naia ekspertiza i reabilitaciia, 2003;2:52-53. (in Russian)

24.Sharopin KA, Berestneva OG, Ivanov VT. Informacionnaia sistema ocenki professional'noj psikhofizicheskoj gotovnosti studentov tekhnicheskogo universiteta [Informational system of assessment of technical university students' professional psycho-physical readiness]. Izvestiia Tomskogo politekhnicheskogo universiteta, 2006;309(3):175-179. (in Russian)

25.Adyrkhaiev SG. Psychophysical condition of visually impaired students during physical education classes. European Scientific Journal, 2014;10(3):62-69.

26.Alexander A Fedyakin, Elena V Kuvaldina. Analysis of Dissertation Research on Physical Education of Students. European Journal of Physical Education and Sport, 2015;7(1):17-23. doi:10.13187/ejpe.2015.7.17

27.Amade-Escot C. Research on content in physical education: theoretical perspectives and current debates. Physical Education \& Sport Pedagogy, 2007;12(3):185-204.

28.Anikieiev DM. Criteria of effectiveness of students' physical education system in higher educational establishments. Physical education of students, 2015;5:3-8. doi:10.15561/20755279.2015.0501

29.Andreassi JL. Psychophysiology. Human Behavior and physiological response. $4^{\text {th }}$ edition. London: Lawrence Erlbaum Associates Publishers; 2000.

30.Bailey R. Phisical education for learning. Continium International Publishing Group; 2010.

31.Green K, Hardman K. Phisical education. Mayer \& Mayer Verlag; 2005.

32.Crocker L, Algina J. Introduction to Classical and Modern Test Theory. New-York: Harcourt Brace Jovanovich; 1986.

33.Hardman K, Green K. Contemporari issues in phisical education. Mayer \& Mayer Verlag; 2011.

34.Kirk D, MacDonald D, O Suliva M. The handbook of physical 
education. Sage; 2006.

35..Kobasa SC, Maddi SR, Kahn S. Hardiness and health: a prospective study. Journal of personality and social psychology, 1982;42(1):168-177. doi: 10.1037/00223514.1.168

36.Nixon JE, Jewett AE. A Introduction to Physical Education. Philadelphia: Saunders; 1980.

37.Munsterberg H. Psychology. General and applied. New York: Appleton; 1915.

38.Pichurin VV. Resilience of students and their readiness for professional functioning. Physical education of students 2015;3:38-43. doi:10.15561/20755279.2015.0305

39.Prosvirina LN, Kolokoltsev MM, Kolchanova MA, Cieslicka Miroslawa, Stankiewicz Blazej. The characteristic of the engine qualities of the students of technical institute of III functional health group (special medical group). Physical Education of Students, 2015;1:43-49. doi:10.15561/207552 79.2015.0107.

40.Tsao W-S. Ophthalmologic abnormalities among students with cognitive impairment in eastern Taiwan: The special group with undetected visual impairment. Journal of the Formosan Medical Association, [Internet]. 2016 Oct [cited 2016 Nov 5]; Available from: http://dx.doi.org/10.1016/j. jfma.2016.06.013

41.Golyaka S.K. The condition of the properties of foundamental nervous processes, functions of memory and attention of sportsmen. Pedagogics, psychology, medical-biological problems of physical training and sports, 2008;9;27-31.

\section{Information about the authors:}

Koryahin V.M.; http://orcid.org/0000-0003-1472-4846; koryahinv@meta.ua; National University Lviv Polytechnic; Str. Bandera, 12, Lviv, 79013, Ukraine.

Blavt O. Z.; http://orcid.org/0000-0001-5526-9339; oksanablavt@mail.ru; National University Lviv Polytechnic; Str. Bandera, 12, Lviv, 79013, Ukraine;

Stadnyk V.V.; orcid.org/0000-0002-2864-4794; vova121212131313@ukr.net; National University Lviv Polytechnic; Str. Bandera, 12, Lviv, 79013, Ukraine.

Cite this article as: Koryahin VM, Blavt OZ, Stadnyk VV. Control of psycho-physiological functions of students with ophthalmologic diseases in the process of physical education. Pedagogics, psychology, medical-biological problems of physical training and sports, 2017;1:23-30. doi:10.15561/18189172.2017.0104

The electronic version of this article is the complete one and can be found online at: http://www.sportpedagogy.org.ua/index.php/PPS/issue/archive

This is an Open Access article distributed under the terms of the Creative Commons Attribution License, which permits unrestricted use, distribution, and reproduction in any medium, provided the original work is properly cited (http://creativecommons.org/licenses/by/4.0/deed.en).

Received: 26.12.2016

Accepted: 05.01.2017; Published: 24.01.2017 